\title{
HSQC-NMR analysis of lignin in woody (Eucalyptus globulus and Picea abies) and non-woody (Agave sisalana) ball-milled plant materials at the gel state
}

\author{
10 ${ }^{\text {th }}$ EWLP, Stockholm, Sweden, August 25-28, 2008
}

\author{
Jorge Rencoret ${ }^{1}$, Gisela Marques ${ }^{1}$, Ana \\ Gutiérrez¹, Lidia Nieto², J. Ignacio Santos², \\ Jesús Jiménez-Barbero², Ángel T. Martínez² \\ and José C. del Río1,*
${ }^{1}$ Instituto de Recursos Naturales y Agrobiología, CSIC, Seville, Spain Spain \\ ${ }^{2}$ Centro de Investigaciones Biológicas, CSIC, Madrid, \\ *Corresponding author. \\ Instituto de Recursos Naturales y Agrobiología, CSIC, \\ PO Box 1052, E-41080, Seville, Spain \\ Phone: +34-954624711 \\ Fax: $+34-954624002$ \\ E-mail: delrio@irnase.csic.es
}

\begin{abstract}
In situ analysis of lignin by 2D NMR of whole plant material was carried out by swelling finely ball-milled samples in deuterated dimethylsulfoxide (DMSO- $d_{6}$ ) and sonicated so that a gel was formed in the NMR analysis tube. Solution HSQC NMR spectra of different plant materials representative for hardwood (Eucalyptus globulus), softwood (Picea abies), and non-woody plants (Agave sisalana) are presented here. The spectra show signals corresponding to those of the main plant constituents, such as lignin and polysaccharides. The lignin signals were assigned by comparing the HSQC spectra of the whole plant materials with the HSQC spectra of their respective milled-wood lignins (MWLs). In general terms, the major lignin structural features, such as the relative abundances of the main lignin substructures, the syringyl/guaiacyl ratios and the extent of $\gamma$-acetylation of the lignin side-chain observed in the HSQC spectra of the whole plant materials, matched those obtained from the HSQC spectra of the isolated MWLs. Therefore, this technique, which needs only minor amounts of lignocellulosic material and minimal sample preparation, can be useful for the rapid screening of plant lignins without the need for tedious and time-consuming lignin isolation procedures.
\end{abstract}

Keywords: 2D NMR; acylation; eucalypt; heteronuclear single quantum correlation (HSQC); lignin structure; milled-wood lignin (MWL); sisal; spruce; wood.

\section{Introduction}

A main challenge in elucidating the structure of lignins is their isolation from wood or other lignocellulosic materi- als in a chemically unaltered form. Several lignin isolation procedures have been developed. The classical procedure (Björkman 1956) consists of aqueous dioxane extraction from ball-milled wood. The yield of the resulting milled-wood lignin (MWL) is usually low (around 33\% related to the Klason lignin content), although this can be increased to some extent by extension of milling time (Lai and Sarkanen 1971). Nevertheless, MWL is considered in the first instance to be approximately representative of native lignin.

Other approaches are: 1) subjecting the milled wood to enzymatic treatment with cellulolytic enzymes to remove most of the carbohydrate components (Chang et al. 1975; Wu and Argyropoulos 2003; Holtman et al. 2004; Hu et al. 2006); 2) completely dissolving ball-milled wood in a solvent system (dimethylsulfoxide, DMSO, and $\mathrm{N}$-methylimidazol, NMI) followed by precipitation in dioxane/water in the course of which lignin and carbohydrate fractions are separated (Fasching et al. 2008); or 3) isolating most of the lignin as lignin-carbohydrate complexes after endoglucanase treatment (Henriksson et al. 2007). However, it is well recognized that these lignin preparations, in particular the MWL due to its low yield, represent only a part of the native lignin in the wood cell wall and may not be representative of the whole lignin present.

Indeed, it has also been demonstrated that MWL can undergo some structural modifications during isolation, especially during the milling process (Fujimoto et al. 2005; Guerra et al. 2006; Hu et al. 2006; Balakshin et al. 2008). Because lignin is intimately interpenetrating the other major components (cellulose and hemicelluloses), it is obvious that its truly native form can only be studied by analytical methods applicable directly on the whole plant material.

Nowadays, the best information on lignin structure related to phenylpropanoid units and inter-unit linkages may be derived from 2D NMR spectroscopy obtained by preparations according to the MWL method (Ralph et al. 1999, 2004; Capanema et al. 2004, 2005; Zhang et al. 2006; del Río et al. 2008; Rencoret et al. 2008a). To obtain more information about the unaltered native lignin, some other methods have recently been proposed for the "in situ" analysis of lignins by 2D NMR of whole plant materials. The application of solvent systems (including DMSO and ionic liquids, such as NMI) is the first successful attempt for fully dissolving finely ground wood that is then acetylated for purification (Lu and Ralph 2003; Kilpeläinen et al. 2007). The mechanically disintegrated and acetylated cell wall is then fully soluble in chloroform allowing the whole lignin to be analyzed 
directly (in the environment of dissolved polysaccharides) by NMR. Acetylation has the advantage to make readily visible the various $\mathrm{OH}$ groups; however, it can result in loss of important structural information since different lignins, mainly from grasses and other herbaceous plants, are known to be naturally acetylated to a high extent (Ralph 1996; Lu and Ralph 2002; del Río et al. 2004, $2007,2008)$, most probably as a mechanism for regulating lignin structure at the monolignol level (Martínez et al. 2008).

The original procedure of Lu and Ralph (2003) was later modified and a perdeuterated solvent system was applied to allow a direct in-tube dissolution and solutionstate NMR of the whole cell wall without derivatization (Yelle et al. 2008). The solvent system contains NMI- $d_{6}$, which needs to be synthesized. Other solvent systems (DMSO/LiCl) have also been proposed that dissolve whole milled wood prepared by as short as $2 \mathrm{~h}$ milling with no significant lignin structural change (Wang et al. 2008). Another recent and simpler approach consists of swelling finely ground plant material in DMSO- $d_{6}$ and forming a gel directly in the NMR tube, which is readily amenable to NMR analysis (Kim et al. 2007, 2008; Rencoret et al. 2008b). This method also needs finely milled plant material, but the milling time (1-4 $\mathrm{h}$ depending on the sample) is far lower than that needed for MWL isolation, thus structural changes of lignin due to milling is kept to a minimum.

The aim of the present work is to contribute to this topical research field. Heteronuclear single quantum correlation (HSQC) solution NMR spectra of different plant materials are presented and the spectral data are semiquantitatively evaluated. Finely ball-milled hardwood (Eucalyptus globulus Labill.), softwood (Picea abies (L.) Karst.), and sisal (Agave sisalana Perrine) as a non-woody plant, were suspended in DMSO- $d_{6}$ in the NMR tube and sonicated for 10-30 min. This treatment leads to the formation of a gel, which is amenable to HSQC-NMR spectroscopy. The spectra will be compared with those of respectively isolated MWL preparations.

\section{Experimental}

\section{Samples}

E. globulus and $P$. abies wood and $A$. sisalana fibers were grounded in a Retsch cutting mill to pass through a 100-mesh screen and then successively extracted with acetone for $8 \mathrm{~h}$ in a Soxhlet extractor and with hot water $\left(100^{\circ} \mathrm{C}\right)$ for $3 \mathrm{~h}$. Klason lignin content was estimated according to Tappi standard T 222 om-88 (Tappi 2004). The extracted sawdust was finely ballmilled in a Retsch $\$ 100$ centrifugal ball at $400 \mathrm{rpm}$ (around $10 \mathrm{~h}$ ) in an agate jar and the balls were from the same material.

\section{Gel formation}

Approximately $100 \mathrm{mg}$ of finely ball-milled wood was suspended in $0.75 \mathrm{ml}$ of DMSO- $d_{6}$ in the NMR tube and sonicated for 10-30 min, depending on the sample, in an ultrasonic cleaning bath (Ultrasons JS 3000513 from Selecta, with a frequency of $40 \mathrm{kHz}$ and $150 \mathrm{~W}$ power consumption), until a homogeneous gel was formed, and HSQC spectra were recorded.

\section{MWL}

Plant material (free of extractives and hot water solubles) was ball milled in toluene during $150 \mathrm{~h}$. Lignin was extracted by dioxane/water $(9: 1, \mathrm{v} / \mathrm{v})$, followed by evaporation of the solvent, and purified as described previously (Björkman 1956). The final yields ranged from $10 \%$ to $15 \%$ based on the Klason lignin content. Around $40 \mathrm{mg}$ of MWL was dissolved in $0.75 \mathrm{ml}$ of DMSO$d_{6}$ for the HSQC experiments.

\section{NMR}

2D NMR spectra were recorded at $25^{\circ} \mathrm{C}$ on a Bruker AVANCE $500 \mathrm{MHz}$ equipped with a z-gradient triple resonance probe in HSQC experiments. The spectral widths were $5000 \mathrm{~Hz}$ and $25000 \mathrm{~Hz}$ for the ${ }^{1} \mathrm{H}$ - and ${ }^{13} \mathrm{C}$-dimensions, respectively. The number of collected complex points was 2048 for ${ }^{1} \mathrm{H}$-dimension with a recycle delay of $5 \mathrm{~s}$. The number of transients was 64 , and 256 time increments were always recorded in ${ }^{13} \mathrm{C}$-dimension. The ${ }^{1} J_{C H}$ used was $140 \mathrm{~Hz}$. The $J$-coupling evolution delay was set to $3.2 \mathrm{~ms}$. Squared cosine-bell apodization function was applied in both dimensions. Prior to Fourier transform, the data matrixes were zero filled up to 1024 points in the ${ }^{13} \mathrm{C}$-dimension. The central solvent (DMSO) peak was used as an internal chemical shift reference point $\left(\delta_{\mathrm{C}} 40.1 ; \delta_{\mathrm{H}} 2.50 \mathrm{ppm}\right)$.

A semiquantitative analysis of the intensities of the HSQC cross-signal was performed (Heikkinen et al. 2003; Liitiä et al. 2003; Zhang and Gellerstedt 2007). Since the cross-signal intensity depends on the particular ${ }^{1} \mathrm{~J}_{\mathrm{CH}}$ value, as well on the $T_{2}$ relaxation time, a direct analysis of the intensities is elusive. Thus, the integration of the cross-signals was performed separately for the different regions of the HSQC spectra, which contain signals that correspond to chemically analogous carbon-proton pairs. For these signals, the ${ }^{1} J_{C H}$ coupling value is relatively similar, their chemical shifts are also similar to each other, hence the error of off-resonance effect is small, and therefore can be used semiquantitatively to estimate the relative abundance of the different species. In the aliphatic oxygenated region, the relative abundance of the different inter-unit linkages were estimated from $\mathrm{C}_{\alpha}-\mathrm{H}_{\alpha}$ correlations (except for cinnamyl alcohol end-groups where $\mathrm{C}_{\gamma}-\mathrm{H}_{\gamma}$ correlations were used) to avoid possible interference from homonuclear ${ }^{1} \mathrm{H}-{ }^{1} \mathrm{H}$ couplings, and the relative abundance of side-chains involved in the different interunit linkages were calculated. In the aromatic region, $\mathrm{C}_{2,6}-\mathrm{H}_{2,6}$ correlations from $\mathrm{S}$ units and $\mathrm{C}_{2}-\mathrm{H}_{2}$ plus $\mathrm{C}_{6}-\mathrm{H}_{6}$ correlations from $G$ units were used to estimate the $S / G$ ratio of lignin. The percentage of lignin acylation in sisal was obtained by integrating the signals from $\mathrm{C}_{\beta}-\mathrm{H}_{\beta}$ correlations in acylated and non-acylated $\beta-O-4^{\prime}$ structures.

\section{Results and discussion}

The HSQC-NMR spectra of the whole plant materials selected for this study, together with the spectra of their respective MWL, are presented in Figure 1. Carbohydrate signals were predominant. They included correlations in the range $\delta_{\mathrm{C}} / \delta_{\mathrm{H}} 60-85 / 2.5-5.5 \mathrm{ppm}$ that partially overlapped with some lignin signals, and the well-resolved anomeric correlations in the range $\delta_{\mathrm{C}} / \delta_{\mathrm{H}}$ 95-105/ 4.2-5.5 ppm. Gel spectra were compared with spectra obtained from the same samples after complete acetylation as described by Lu and Ralph (2003) (data not shown). The comparison showed lower intensities of the cellulose signals (compared with those of the hemicelluloses and lignin signals) when the spectra were 


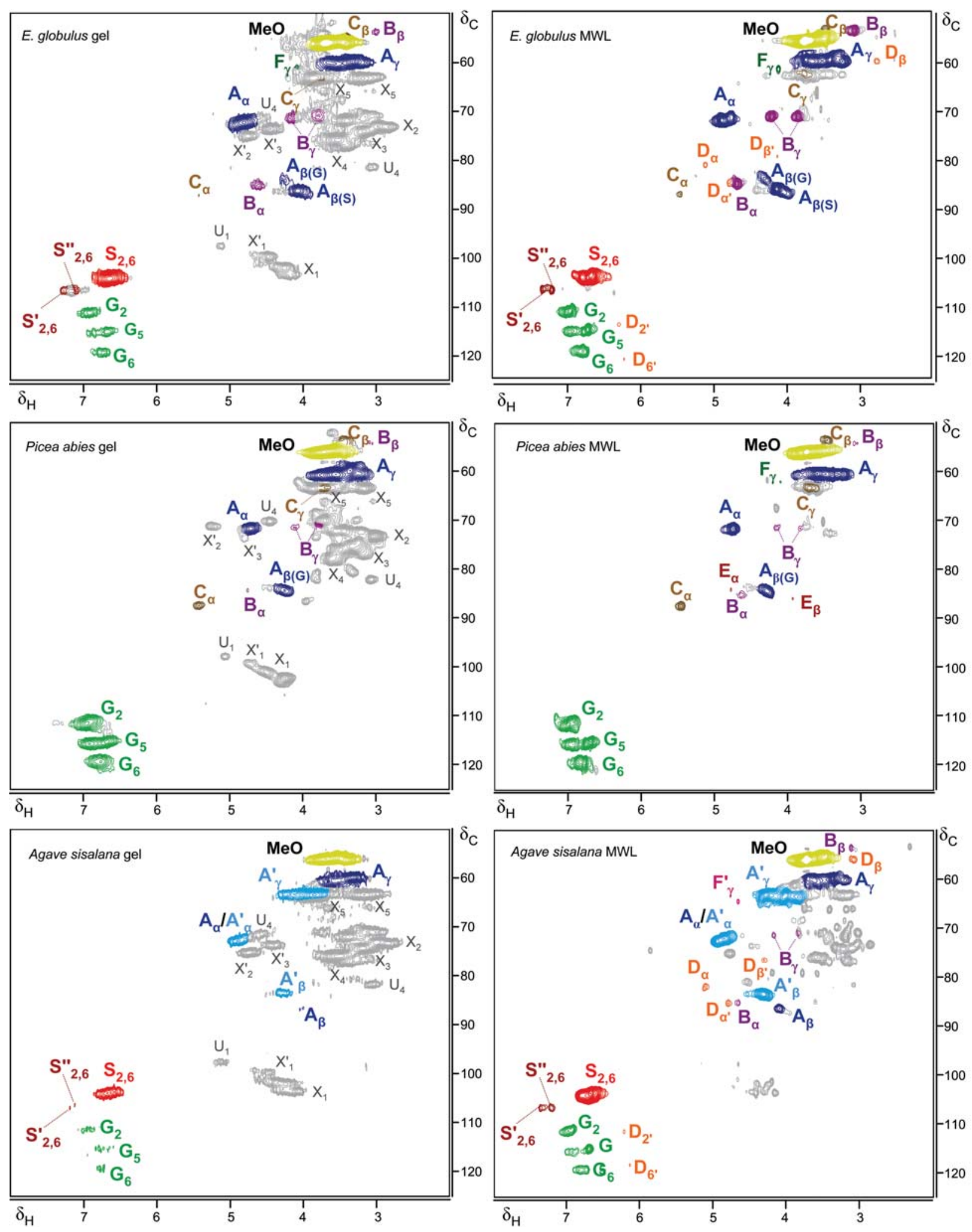

Figure 1 Expanded HSQC NMR $\left(\delta_{C} / \delta_{H} 50-125 / 2.0-8.0 \mathrm{ppm}\right)$ spectra of eucalypt wood, spruce wood and sisal fibers, and of their respective MWL preparations. The lignin structures identified, and the main polysaccharide units, are presented in Figure 2. See Table 1 for assignment of the different lignin cross-signals.

acquired at the gel state. This fact, which is probably related to the crystalline moiety of cellulose, is an advantage for the analysis of lignins as already pointed out by Kim et al. (2008). Therefore, hemicelluloses cross-signals were predominant in the gel NMR spectra obtained, which were tentatively assigned to 'normal' $(\mathbf{X})$ and partially acetylated $\left(\mathbf{X}^{\prime}\right)$ neutral sugars, and 4-methyluronic acid $(\mathbf{U})$ units.

Cellulose signals were also observed being partially overlapping with some of the signals of lignin and hemi- 
celluloses. The hemicelluloses signals would correspond to 4-methylglucuronic-substituted and partially-acetylated xylan in eucalypt and sisal, and partially-acetylated glucomannan (and some pectin) in spruce, in agreement with previous studies (Evtuguin et al. 2003; Hannuksela and Hervé du Penhoat 2004; Marques et al. 2008). Xylose acetylation (at C2/C3) would also affect the chemical shifts of contiguous carbons, and the main effect on the acetate-bearing $C$ is discussed below. The existence of these two types of hemicelluloses was evidenced by differences in the anomeric cross-signals, as shown for similar samples (Yelle et al. 2008), but especially by fingerprint $\mathrm{C}_{2}-\mathrm{H}_{2}$ correlations for the acetylated xylose $\left(\delta_{\mathrm{C}} / \delta_{\mathrm{H}} 75.4 / 4.74 \mathrm{ppm}\right)$ and mannose units $\left(\delta_{\mathrm{C}} / \delta_{\mathrm{H}} 71.1 /\right.$ $5.23 \mathrm{ppm})$. A similar acetylation degree at the xylose $\mathrm{C}_{3}{ }^{-}$ position of both eucalypt and sisal xylan was evidenced by the corresponding signal $\left(\delta_{C} / \delta_{H} 73.7 / 4.43 \mathrm{ppm}\right)$. Interestingly, lignin signals could also be clearly observed in all the HSQC spectra of whole plant materials, despite the fact that lignin is not their main constituent $(27 \%$ and $18 \%$ Klason lignin content for spruce and eucalypt, respectively, and only $11 \%$ Klason lignin for sisal). Unequivocal assignment of the lignin signals was obtained by comparing the HSQC spectra of the whole plant materials with those of their respective MWL. Other 2D NMR studies on lignin reported in the literature were helpful for signal assignment (Ämmälahti et al. 1998; Ralph et al. 1999, 2004; Liitiä et al. 2003; Capanema et al. 2004, 2005; Ibarra et al. 2007a,b; del Río et al. 2008; Rencoret et al. 2008a). The main lignin cross-signals observed in the HSQC spectra are listed in Table 1, and the main lignin substructures identified in the plant materials are presented in Figure 2.
The HSQC spectra presented in Figure 1 show only the region $\delta_{\mathrm{C}} / \delta_{\mathrm{H}} 50-125 / 2.0-8.0 \mathrm{ppm}$, where the main oxygenated aliphatic and aromatic lignin signals appear. All the spectra from whole plant materials showed prominent signals corresponding to $\beta-O-4^{\prime}$ alkyl-aryl ether linkages (substructures $\mathbf{A}$ and $\mathbf{A}^{\prime}$ ), as also observed in the HSQC of their respective MWL. The $\mathrm{C}_{\gamma}-\mathrm{H}_{\gamma}$ correlations in $\beta-O-4^{\prime}$ substructures in eucalypt and spruce woods were observed at $\delta_{C} / \delta_{H} 60.0 / 3.38$ and $3.71 \mathrm{ppm}$, partially overlapped with cellulose $\mathrm{C}_{6}-\mathrm{H}_{6}$ cross-signals. The HSQC spectrum of sisal fibers clearly shows the presence of intense signals corresponding to acylated $\gamma$-carbon in the range between $\delta_{\mathrm{C}} / \delta_{\mathrm{H}} 63.5 / 3.83$ and $4.30 \mathrm{ppm}$, together with the presence of signals from normal hydroxylated $\gamma$-carbon (at $\delta_{\mathrm{C}} / \delta_{\mathrm{H}} \quad 60.0 / 3.38$ and $3.71 \mathrm{ppm}$ ), as can also be observed in the HSQC of sisal MWL. The HSQC spectrum of sisal fibers, therefore, undoubtedly demonstrates that this lignin is extensively acylated and that acylation takes place only at the $\gamma$ position of the lignin side-chain. Previous studies have indicated that acylation in sisal occurs exclusively with acetate groups and predominantly over syringyl units (del Río et al. 2004, 2007, 2008). The presence of acetylated lignin units in the HSQC of sisal fibers excludes the possibility of acetylation as an artifact produced during the MWL isolation protocol.

The $\mathrm{C}_{\alpha}-\mathrm{H}_{\alpha}$ correlations in $\beta-O-4^{\prime}$ substructures ( $A$ and $\mathbf{A}^{\prime}$ ) were observed at $\delta_{\mathrm{C}} / \delta_{\mathrm{H}} 72.3 / 4.86 \mathrm{ppm}$ for $\beta-O-4^{\prime}$ substructures linked to $S$ units (in eucalypt wood and sisal fibers) and at $\delta_{\mathrm{C}} / \delta_{\mathrm{H}} 71.6 / 4.73 \mathrm{ppm}$ for $\beta-O-4^{\prime}$ substructures linked to $\mathrm{G}$ units (in spruce wood). The $\mathrm{C}_{\beta}-\mathrm{H}_{\beta}$ correlations were observed in the range at $\delta_{C} / \delta_{H} 83.6-86.5 /$ 4.10-4.64 ppm, and also differed among the samples. In

Table 1 Assignment of main lignin ${ }^{13} \mathrm{C}-{ }^{-1} \mathrm{H}$ cross-signals in the HSQC spectra shown in Figure 1.

\begin{tabular}{|c|c|c|}
\hline Labels & $\delta_{\mathrm{C}} / \delta_{\mathrm{H}}(\mathrm{ppm})$ & Assignment \\
\hline $\mathrm{B}_{\beta}$ & $53.7 / 3.12$ & $\mathrm{C}_{\beta}-\mathrm{H}_{\beta}$ in $\beta-\beta^{\prime}$ (resinol) substructures (B) \\
\hline $\mathrm{C}_{\beta}$ & $53.7 / 3.44$ & $\mathrm{C}_{\beta}-\mathrm{H}_{\beta}$ in $\beta-5^{\prime}$ (phenylcoumaran) substructures (C) \\
\hline$A_{\gamma}$ & 60.0/3.38-3.71 & $\mathrm{C}_{\gamma}-\mathrm{H}_{\gamma}$ in $\beta-O-4^{\prime}$ substructures $(\mathbf{A})$ and others \\
\hline$D_{\beta}$ & $60.3 / 2.75$ & $\mathrm{C}_{\beta}^{\prime}-\mathrm{H}_{\beta}^{\prime}$ in $\beta-1^{\prime}$ (spirodienone) substructures (D) \\
\hline $\mathrm{F}_{\gamma}$ & $61.9 / 4.09$ & $\mathrm{C}_{\gamma}-\mathrm{H}_{\gamma}$ in cinnamyl alcohol end-groups $(\mathbf{F})$ \\
\hline $\mathrm{C}_{\gamma}$ & $63.3 / 3.66$ & $\mathrm{C}_{\gamma}-\mathrm{H}_{\gamma}$ in $\beta-5^{\prime}$ (phenylcoumaran) substructures (C) \\
\hline$A_{\gamma}^{\prime}$ & $63.8 / 3.83-4.30$ & $\mathrm{C}_{\gamma}-\mathrm{H}_{\gamma}$ in $\gamma$-acetylated $\beta-O-4^{\prime}$ substructures $\left(\mathbf{A}^{\prime}\right)$ and others \\
\hline $\mathrm{F}_{\gamma}^{\prime}$ & $64.7 / 4.67$ & $\mathrm{C}_{\gamma}-\mathrm{H}_{\gamma}$ in cinnamyl acetate end-groups $\left(\mathbf{F}^{\prime}\right)$ \\
\hline $\mathrm{B}_{\gamma}$ & $71.7 / 3.81$ and 4.17 & $\mathrm{C}_{\gamma}-\mathrm{H}_{\gamma}$ in $\beta-\beta^{\prime}$ (resinol) substructures (B) \\
\hline $\mathrm{A}_{\alpha} / \mathrm{A}_{\alpha}^{\prime}$ & $72.3 / 4.86$ and $71.6 / 4.73$ & $\mathrm{C}_{\alpha}-\mathrm{H}_{\alpha}$ in $\beta-O-4^{\prime}$ substructures $\left(\mathbf{A}\right.$ and $\left.\mathbf{A}^{\prime}\right)$ \\
\hline$D_{\beta^{\prime}}$ & $79.8 / 4.11$ & $\mathrm{C}_{\beta^{\prime}}-\mathrm{H}_{\beta^{\prime}}$ in $\beta-1^{\prime}$ (spirodienone) substructures (D) \\
\hline $\mathrm{D}_{\alpha}$ & $81.7 / 5.09$ & $\mathrm{C}_{\alpha}-\mathrm{H}_{\alpha}$ in $\beta-1^{\prime}$ (spirodienone) substructures (D) \\
\hline$A_{\beta}^{\prime}$ & $83.6 / 4.32$ & $\mathrm{C}_{\beta}-\mathrm{H}_{\beta}$ in $\gamma$-acetylated $\beta-O-4^{\prime}$ substructures $\left(\mathbf{A}^{\prime}\right)$ \\
\hline$E_{\alpha}$ & $83.6 / 4.83$ & $\mathrm{C}_{\alpha}-\mathrm{H}_{\alpha}$ in 5-5' (dibenzodioxocin) substructures (E) \\
\hline$A_{\beta}(G)$ & $84.1 / 4.28$ & $\mathrm{C}_{\beta}-\mathrm{H}_{\beta}$ in $\beta-O-4^{\prime}$ substructures $(A)$ linked to a $\mathrm{G}$ unit \\
\hline $\mathrm{B}_{\alpha}$ & $85.4 / 4.64$ & $\mathrm{C}_{\alpha}-\mathrm{H}_{\alpha}$ in $\beta-\beta^{\prime}$ (resinol) substructures (B) \\
\hline$E_{\beta}$ & $85.9 / 3.88$ & $\mathrm{C}_{\beta}-\mathrm{H}_{\beta}$ in $5-5^{\prime}$ (dibenzodioxocin) substructures $(\mathrm{E})$ \\
\hline$A_{\beta}(S)$ & $86.5 / 4.10$ & $\mathrm{C}_{\beta}-\mathrm{H}_{\beta}$ in $\beta-O-4^{\prime}$ substructures $(A)$ linked to a $S$ unit \\
\hline$D_{\alpha}^{\prime}$ & 86.6/4.39 & $\mathrm{C}_{\alpha^{\prime}}-\mathrm{H}_{\alpha^{\prime}}$ in $\beta-1^{\prime}$ (spirodienone) substructures (D) \\
\hline $\mathrm{C}_{\alpha}$ & $87.7 / 5.45$ & $\mathrm{C}_{\alpha}-\mathrm{H}_{\alpha}$ in $\beta-5^{\prime}$ (phenylcoumaran) substructures (C) \\
\hline $\mathrm{S}_{2,6}$ & $103.8 / 6.68$ & $\mathrm{C}_{2}-\mathrm{H}_{2}$ and $\mathrm{C}_{6}-\mathrm{H}_{6}$ in syringyl units $(\mathbf{S})$ \\
\hline $\mathrm{S}_{2,6}^{\prime, 6} \mathrm{~S}_{2,6}^{\prime \prime}$ & $106.7 / 7.36$ and 7.21 & $\mathrm{C}_{2}-\mathrm{H}_{2}$ and $\mathrm{C}_{6}-\mathrm{H}_{6}$ in $\mathrm{C}_{\alpha}$-oxidized syringyl units $\left(\mathbf{S}^{\prime}\right.$ and $\left.\mathbf{S}^{\prime \prime}\right)$ \\
\hline $\mathrm{G}_{2}$ & $111.5 / 6.99$ & $\mathrm{C}_{2}-\mathrm{H}_{2}$ in guaiacyl units $(\mathbf{G})$ \\
\hline $\mathrm{D}_{2^{\prime}}$ & $114.1 / 6.26$ & $\mathrm{C}_{2^{\prime}}-\mathrm{H}_{2^{\prime}}$ in $\beta-1^{\prime}$ (spirodienone) substructures (D) \\
\hline $\mathrm{G}_{5}$ & $115.2 / 6.71$ and 6.94 & $\mathrm{C}_{5}-\mathrm{H}_{5^{\prime}}$ in guaiacyl units $(\mathbf{G})$ \\
\hline$D_{6^{\prime}}$ & $119.5 / 6.08$ & $\mathrm{C}_{6^{\prime}} \mathrm{H}_{6^{\prime}}$ in $\beta-1^{\prime}$ (spirodienone) substructures (D) \\
\hline $\mathrm{G}_{6}$ & $119.5 / 6.83$ & $\mathrm{C}_{6}-\mathrm{H}_{6}$ in guaiacyl units $(\mathbf{G})$ \\
\hline
\end{tabular}


<smiles>CCOc1c(OC)cc(C(O)C(CO)Oc2c(Cl)cc(C)cc2OC)cc1OC</smiles>

A<smiles>CCOc1c(OC)cc(C(O)C(=COc2c(O)cc(I)cc2OC)OCC(C)=O)cc1OC</smiles>

$A^{\prime}$<smiles>CCOc1cc(C2OCC3C(c4cc(OC)c(OC(C)C)c(OC)c4)=COC32)cc(OC)c1OC</smiles>

B<smiles>CCOc1c(OC)cc(C2Oc3c(OC)cc(C(C)(C)C)cc3C2CO)cc1OC</smiles>

C<smiles>[3H]C(CO)[C@@H]1OC(c2cc(OC)c(OC)c(OC)c2)C(CO)C12C=C(OC)C(=O)C(O)C2</smiles>

D<smiles>COc1cc(C(C)C)cc(-c2cc(C(C)(C)C)cc(OC)c2OC(CO)c2ccc(C(C)C)cc2)c1O</smiles>

E<smiles>COc1cc(C=CCO)cc(OC)c1OC</smiles>

$F$<smiles>CCOc1c(OC)cc(C=CCOC(C)=O)cc1OC</smiles>

$F^{\prime}$<smiles>COc1ccc(C(O)C(C)(C)O)cc1OC</smiles>

G<smiles>[Y]C1C(O)OC(OC)=C(O)C1O</smiles>

X<smiles>COc1cc(C(O)C(C)C)cc(OC)c1OC</smiles>

$\mathrm{S}$<smiles>COc1cc(C(=O)C(C)(C)C)cc(OC)c1O</smiles>

$\mathbf{S}^{\prime}$<smiles>CCOc1c(OC)cc(C(=O)O)cc1OC</smiles>

S"

Figure 2 Lignin substructures, and main polysaccharide units, observed in the HSQC spectra: (A) $\beta-O-4^{\prime}$ linkages; $\left(\mathbf{A}^{\prime}\right) \beta-O-4^{\prime}$ linkages with $\gamma$-acetyl groups; (B) resinol structures formed by $\beta-\beta^{\prime}, \alpha-O-\gamma^{\prime}$, and $\gamma-O-\alpha^{\prime}$ linkages; (C) phenylcoumaran structures formed by $\beta-5^{\prime}$ and $\alpha-O-4^{\prime}$ linkages; (D) spirodienone structures formed by $\beta-1^{\prime}, \alpha-O-\alpha^{\prime}$ linkages; (E) dibenzodioxocin structures formed by $5^{\prime}-5^{\prime \prime}, \alpha-O-4^{\prime}$ and $\beta-O-4^{\prime \prime}$ linkages; (F) cinnamyl alcohol end-groups; $\left(\mathbf{F}^{\prime}\right)$ cinnamyl acetate end-groups; (G) guaiacyl unit; (S) syringyl unit; ( $\left.\mathbf{S}^{\prime}\right)$ oxidized syringyl unit bearing a carbonyl group at $\mathrm{C}_{\alpha}$ (phenolic); $\left(\mathbf{S}^{\prime \prime}\right)$ oxidized syringyl unit bearing a carboxyl group at $\mathrm{C}_{\alpha} ;(\mathbf{X})$ xylopyranose $(\mathrm{R}, \mathrm{OH})$ or gluco/mannopyranose $\left(\mathrm{R}, \mathrm{CH}_{2} \mathrm{OH}\right)$ units; $\left(\mathbf{X}^{\prime}\right)$ acetylated xylopyranose $(\mathrm{R}, \mathrm{OH})$ or acetylated gluco/mannopyranose $\left(\mathrm{R}, \mathrm{CH}_{2} \mathrm{OH}\right)$ units $\left(\mathrm{R}^{\prime}\right.$ or $\left.\mathrm{R}^{\prime \prime}, \mathrm{CH}_{3}-\mathrm{C}=\mathrm{O}\right)$; and $(\mathbf{U})$ 4-O-methylglucuronic/4-O-methylgalacturonic acid.

eucalypt wood, the $\mathrm{C}_{\beta}-\mathrm{H}_{\beta}$ correlations were observed at $\delta_{\mathrm{C}} / \delta_{\mathrm{H}} 86.5 / 4.10$ in $\beta-O-4^{\prime}$ substructures linked to an $\mathrm{S}$ unit and at $\delta_{\mathrm{C}} / \delta_{\mathrm{H}} 84.1 / 4.28$ in $\beta-O-4^{\prime}$ substructures linked to a $\mathrm{G}$ unit. In spruce, only the latest $\mathrm{C}_{\beta}-\mathrm{H}_{\beta}$ correlation (typical of a G-lignin) was observed, while in sisal the $\mathrm{C}_{\beta}$ $\mathrm{H}_{\beta}$ correlations were observed at $\delta_{\mathrm{C}} / \delta_{\mathrm{H}} 86.5 / 4.10 \mathrm{ppm}$ in normal $\gamma$-hydroxylated $\beta-O-4^{\prime}$ aryl ether substructures (A) but shifted to $\delta_{C} / \delta_{H} 83.6 / 4.32$ ppm in $\gamma$-acylated $\beta-O-4^{\prime}$ substructures $\left(\mathbf{A}^{\prime}\right)$. Therefore, it should be possible to use these differentiating $\mathrm{C}_{\beta}-\mathrm{H}_{\beta}$ correlations in acylated and non-acylated $\beta-0-4^{\prime}$ structures to estimate the percentage of lignin acylation in sisal.

Unfortunately, the signal for the $\mathrm{C}_{\beta}-\mathrm{H}_{\beta}$ correlations in acylated $\beta-O-4^{\prime}$ structures $\left(\delta_{\mathrm{C}} / \delta_{\mathrm{H}} 83.6 / 4.32 \mathrm{ppm}\right)$ could overlap with the $\mathrm{C}_{\beta}-\mathrm{H}_{\beta}$ correlation signal in those of nonacylated $\beta-O-4^{\prime}$ substructures including a second $\mathrm{G}$ unit, as found in eucalypt gel and $\mathrm{MWL}\left(\delta_{\mathrm{C}} / \delta_{\mathrm{H}} 84.1 / 4.28 \mathrm{ppm}\right)$ and special attention must therefore be given when estimating the extent of lignin acylation. However, the presence of $\gamma$-acylating groups in sisal $\beta-O-4^{\prime}$ structures is 
confirmed by the strong $\mathrm{C}_{\gamma}-\mathrm{H}_{\gamma}$ correlation signal $\left(\delta_{\mathrm{C}} / \delta_{\mathrm{H}}\right.$ 64/3.8-4.3 ppm). This conclusion is also supported by modified DFRC analyses (del Río et al. 2008).

Signals for other lignin substructures were also observed in the HSQC spectra of the plant materials. Some of these signals correspond to minor structures, which can only be clearly observed in the HSQC of the MWLs. Strong signals for resinol $\left(\beta-\beta^{\prime} / \alpha-O-\gamma^{\prime} / \gamma-O-\alpha^{\prime}\right)$ substructures (B) were observed in the HSQC spectrum of eucalypt wood, with their $\mathrm{C}_{\alpha}-\mathrm{H}_{\alpha}, \mathrm{C}_{\beta}-\mathrm{H}_{\beta}$ and the double $\mathrm{C}_{\gamma}-\mathrm{H}_{\gamma}$ correlations at $\delta_{\mathrm{C}} / \delta_{\mathrm{H}} 85.5 / 4.64,53.7 / 3.12$ and $71.7 / 3.83$ and $4.30 \mathrm{ppm}$, respectively. Resinol substructures (B) were also observed, although in lower amounts, in the HSQC spectrum of spruce wood. Resinols (B) could not be detected in the HSQC spectrum of sisal fibers due to its very low lignin content and the low abundance of these substructures owing to blocking of the $\gamma$ carbon in acetylated monolignols (del Río et al. 2008; Martínez et al. 2008); nevertheless, small signals could be seen in the HSQC spectrum of its MWL.

Phenylcoumaran $\left(\beta-5^{\prime} / \alpha-O-4\right)$ substructures (C) were observed in the HSQC spectrum of spruce and eucalypt woods, the signals for their $\mathrm{C}_{\alpha}-\mathrm{H}_{\alpha}$ and $\mathrm{C}_{\beta}-\mathrm{H}_{\beta}$ correlations being observed at $\delta_{C} / \delta_{H} 87.7 / 5.45$ and 53.7/3.44 ppm, respectively, and that of $\mathrm{C}_{\gamma}-\mathrm{H}_{\gamma}$ correlation overlapping with xylan $\mathrm{C}_{5}-\mathrm{H}_{5}$ cross-signals around $\delta_{\mathrm{C}} / \delta_{\mathrm{H}}$ 63.3/ $3.66 \mathrm{ppm}$. Signals for spirodienone substructures (D) were clearly seen in the HSQC spectra of the MWL of eucalypt and sisal, with the $\mathrm{C}_{\alpha}-\mathrm{H}_{\alpha}, \mathrm{C}_{\alpha^{\prime}}-\mathrm{H}_{\alpha^{\prime}}, \mathrm{C}_{\beta}-\mathrm{H}_{\beta}$, and $\mathrm{C}_{\beta^{\prime}}-\mathrm{H}_{\beta^{\prime}}$ correlations at $\delta_{\mathrm{C}} / \delta_{\mathrm{H}} 81.7 / 5.09,86.6 / 4.39,60.3 /$ 2.75 , and 79.8/4.11 ppm, respectively. Spirodienones could only be observed in the HSQC of eucalypt wood with low intensity. Likewise, dibenzodioxocin structures (E), which were clearly observed in the HSQC of the MWL of spruce, with the $\mathrm{C}_{\alpha}-\mathrm{H}_{\alpha}$ and $\mathrm{C}_{\beta}-\mathrm{H}_{\beta}$ correlations at $\delta_{\mathrm{C}} / \delta_{\mathrm{H}}$ 83.6/4.83 and 85.9/3.88, respectively, were observed with low intensity in the HSQC spectrum of spruce wood.

Finally, cinnamyl alcohol end-groups (F) were only observed in the HSQC of eucalypt wood, with the $\mathrm{C}_{\gamma}-\mathrm{H}_{\gamma}$ correlation at $\delta_{\mathrm{C}} / \delta_{\mathrm{H}} 61.9 / 4.09 \mathrm{ppm}$, but were not detected in the HSQC of spruce wood due to their low abundance. Moreover, in sisal MWL, the cinnamyl alcohol end-groups $\left(\mathbf{F}^{\prime}\right)$ were found to be acetylated at the $\gamma$ carbon and the signal of the $\mathrm{C}_{\gamma}-\mathrm{H}_{\gamma}$ correlation shifted to $\delta_{\mathrm{C}} / \delta_{\mathrm{H}} 64.0 / 4.69 \mathrm{ppm}$, though this signal could not be observed in the HSQC spectrum of sisal fibers.
The main lignin cross-signals present in the aromatic region of the HSQC spectra correspond to the aromatic rings of the different lignin units. Signals from syringyl (S) and guaiacyl $(\mathrm{G})$ units could be clearly observed in all the spectra of whole plant materials matching those of their respective signals in MWLs (Figure 1). Eucalypt and sisal (two angiosperms) contained $S$ and $G$ units, while spruce (a gymnosperm) had only $G$ units. No traces of $p$ hydroxyphenyl $(\mathrm{H})$ units could be observed in any of the spectra of the plant materials, in accordance with their absence in the HSQC spectra of their MWL preparations.

The $S$ units showed a prominent signal for the $\mathrm{C}_{2,6}-\mathrm{H}_{2,6}$ correlation at $\delta_{\mathrm{C}} / \delta_{\mathrm{H}} 103.8 / 6.68 \mathrm{ppm}$, while the $\mathrm{G}$ units showed different correlations for $\mathrm{C}_{2}-\mathrm{H}_{2}\left(\delta_{\mathrm{C}} / \delta_{\mathrm{H}}\right.$ 111.5/ $6.99 \mathrm{ppm}), \mathrm{C}_{5}-\mathrm{H}_{5}\left(\delta_{\mathrm{C}} / \delta_{\mathrm{H}} 115.2 / 6.71\right.$ and 6.94), and $\mathrm{C}_{6}-\mathrm{H}_{6}$ $\left(\delta_{\mathrm{C}} / \delta_{\mathrm{H}} 119.5 / 6.83 \mathrm{ppm}\right)$. The double $\mathrm{C}_{5}-\mathrm{H}_{5}$ signal revealed some heterogeneity among the $\mathrm{G}$ units, especially affecting the $\mathrm{C}_{5}-\mathrm{H}_{5}$ correlation, probably because it is due to different substituents at $\mathrm{C}_{4}$ (e.g., phenolic or etherified in different substructures). The strong displacement of the cross-signal at $\delta_{\mathrm{C}} / \delta_{\mathrm{H}} 115.2 / 6.94$ after in vitro acetylation (not shown here) indicates that this signal corresponds to phenolic $G$ units. Signals corresponding to $\mathrm{C}_{2,6}-\mathrm{H}_{2,6}$ correlations in $\mathrm{C}_{\alpha}$-oxidized $S$ units $\left(\mathbf{S}^{\prime}\right.$ and $\left.\mathbf{S}^{\prime \prime}\right)\left(\delta_{\mathrm{C}} / \delta_{\mathrm{H}}\right.$ 106.7/7.36 and 7.21 ppm, respectively) (Ralph et al. 2004; Ibarra et al. 2007b) were present in the HSQC spectra of the eucalypt wood and sisal fiber, as also observed in their MWL. The relative abundance of these oxidized moieties estimated from the HSQC is similar (approximately $10 \%$ of total S-lignin units) in the whole eucalypt wood and in its MWL. This fact indicates that these moieties might exist as such in the native eucalypt lignin, although their provenance from the milling process cannot be completely ruled out. In the case of sisal fibers, the signals were very weak in the HSQC spectrum.

The major lignin structural features are listed in Table 2 for both plant material and MWL, such as the percentage of various side-chains, the $S / G$ ratios, and the percentage of $\gamma$-acylation (estimated from the $\mathrm{C}_{\beta}-\mathrm{H}_{\beta}$ correlations in acylated and non-acylated $\beta-O-4$ ' structures). The relative abundance of various types of side-chains were calculated and referred to the amount of total sidechains. As expected, the main lignin substructures were the $\beta-O-4^{\prime}$-linked ones, followed by $\beta-\beta^{\prime}$ resinol substructures in the case of eucalypt wood and $\beta-5^{\prime}$ phenylcoumaran and $\beta-\beta^{\prime}$ resinol substructures in spruce

Table 2 Relative abundance of main inter-unit linkages (as percentages of side-chains involved), percentage of $\gamma$-acylation of the side-chain, and S/G ratio of lignin in the selected lignocellulosic materials.

\begin{tabular}{|c|c|c|c|c|c|c|}
\hline & \multicolumn{2}{|c|}{ Eucalypt } & \multicolumn{2}{|c|}{ Spruce } & \multicolumn{2}{|c|}{ Sisal } \\
\hline & Wood & MWL & Wood & MWL & Fiber & MWL \\
\hline \multicolumn{7}{|l|}{ Linkage abundance (\%) } \\
\hline$\beta-O-4^{\prime}$ aryl ether $\left(\mathbf{A}, \mathbf{A}^{\prime}\right)$ & 80 & 76 & 69 & 65 & 100 & 85 \\
\hline$\beta-\beta^{\prime}$ resinols $(\mathbf{B})$ & 14 & 17 & 10 & 11 & 0 & 4 \\
\hline$\beta-5^{\prime}$ phenylcoumarans (C) & 2 & 2 & 18 & 18 & 0 & 2 \\
\hline$\beta-1^{\prime}$ spirodienones (D) & 2 & 2 & 0 & 0 & 0 & 7 \\
\hline 5-5' dibenzodioxocins (E) & 0 & 0 & 3 & 5 & 0 & 0 \\
\hline Cinnamyl alcohol end-groups (F,F') & 2 & 3 & 0 & 1 & 0 & 2 \\
\hline Percentage of $\gamma$-acylation ${ }^{a}$ & 0 & 0 & 0 & 0 & 70 & 72 \\
\hline S/G ratio & 2.8 & 2.9 & 0 & 0 & 3.6 & 3.9 \\
\hline
\end{tabular}

${ }^{a}$ Estimated from the $\mathrm{C}_{\beta}-\mathrm{H}_{\beta}$ correlations in acylated and non-acylated $\beta-\mathrm{O}-4^{\prime}$ structures. 
wood. In sisal fibers, the $\beta-O-4^{\prime}$ aryl ether linkage was also the most predominant with only traces of other structures that could only be observed in its MWL. Structures present in low abundances (i.e., spirodienones and dibenzodioxocins) could hardly be seen in the HSQC spectra of whole plant materials. This is especially true for sisal due to its low lignin content. Moreover, the lignin from sisal is extensively acetylated at the $\gamma$-carbon of the side-chain, being very different from the other two lignins. The percentage of lignin acetylation $(70 \%)$ of sisal matched that calculated from the HSQC of its MWL (del Río et al. 2008). Finally, the lignin S/G ratios calculated from the HSQC spectra of the whole plant materials also closely matched those calculated from the MWL preparations.

\section{Conclusions}

HSQC-NMR of DMSO- $d_{6}$ gels of ball-milled plant materials seems to be an efficient method for the rapid "in situ" analysis of lignin in plants, without the need of prior lignin isolation. The method requires only very low amounts of sample and can be used for rapid characterization of the major structural features of plant lignins (i.e., inter-unit linkages, S/G ratios and presence and extent of $\gamma$-acylation of the lignin side-chain). The main lignin structures as well as the $S / G$ ratios and the extent of lignin acetylation closely matched those obtained from the MWL. The similarities between the HSQC of whole plant materials and the isolated MWL indicate that MWL is still a reliable and representative preparation of the native lignin that can be used for comprehensive lignin structural analysis. Although ball-milling and sonication would induce some structural changes, the low milling and sonication times used keeps the possibilities of lignin structural modification to the minimum. However, a major drawback of the method is the inability to perform HMBC experiments and to detect minor lignin structures in plant materials with low lignin contents.

\section{Acknowledgements}

This study was supported by the Spanish Ministry of Science and Innovation (projects AGL2005-01748, BIO2005-03569 and BIO2008-01533), the CSIC (project 2006-4-0I-039) and the European Commission (BIORENEW project NMP2-CT-2006026456). J.R. thanks the CSIC for an I3P fellowship and G.M. thanks the Spanish MEC for an FPI fellowship.

\section{References}

Ämmälahti, E., Brunow, G., Bardet, M., Robert, D., Kilpeläinen, I. (1998) Identification of side-chain structures in a poplar lignin using three-dimensional HMQC-HOHAHA NMR spectroscopy. J. Agric. Food Chem. 46:5113-5117.

Balakshin, M.Y., Capanema, E.A., Chang, H.-M. (2008) Recent advances in the isolation and analysis of lignins and lignincarbohydrate complexes. In: Characterization of Lignocellulosic Materials. Ed. Hu, T.Q. Blackwell Publishing Ltd., Oxford, UK. pp. 148-170.
Björkman, A. (1956) Studies on finely divided wood. Part I. Extraction of lignin with neutral solvents. Sven. Papperstidn. 13:477-485.

Capanema, E.A., Balakshin, M.Y., Kadla, J.F. (2004) A comprehensive approach for quantitative lignin characterization by NMR spectroscopy. J. Agric. Food Chem. 52:1850-1860.

Capanema, E.A., Balakshin, M.Y., Kadla, J.F. (2005) Quantitative characterization of a hardwood milled wood lignin by nuclear magnetic resonance spectroscopy. J. Agric. Food Chem. 53:9639-9649.

Chang, H., Cowling, E., Brown, W. (1975) Comparative studies on cellulolytic enzyme lignin and milled wood lignin of sweetgum and spruce. Holzforschung 29:153-159.

del Río, J.C., Gutiérrez, A., Martínez, A.T. (2004) Identifying acetylated lignin units in non-wood fibers using pyrolysis-gas chromatography/mass spectrometry. Rapid Commun. Mass Spectrom. 18:1181-1185.

del Río, J.C., Marques, G., Rencoret, J., Martínez, A.T., Gutiérrez, A. (2007) Occurrence of naturally acetylated lignin units. J. Agric. Food Chem. 55:5461-5468.

del Río, J.C., Rencoret, J., Marques, G., Gutiérrez, A., Ibarra, D., Santos, J.I., et al. (2008) Highly acylated (acetylated and/or $p$-coumaroylated) native lignins from diverse herbaceous plants. J. Agric. Food Chem. 56:9525-9534.

Evtuguin, D.V., Tomás, J.L., Silva, A.M., Neto, C.P. (2003) Characterization of an acetylated heteroxylan from Eucalyptus globulus Labill. Carbohyd. Res. 338:597-604.

Fasching, M., Schröeder, P., Wollboldt, R.P., Weber, H.K., Sixta, H. (2008) A new and facile method for isolation of lignin from wood based on complete wood dissolution. Holzforschung 62:15-23.

Fujimoto, A., Matsumoto, Y., Chang, H.-M., Meshitsuka, G. (2005) Quantitative evaluation of milling effects on lignin structure during the isolation process of milled wood lignin. J. Wood Sci. 51:89-91.

Guerra, A., Filpponen, I., Lucia, L., Saquing, C., Baumberger, S., Argyropoulos, D.S. (2006) Toward a better understanding of the lignin isolation process from wood. J. Agric. Food Chem. 54:5939-5947.

Hannuksela, T., Hervé du Penhoat, C. (2004) NMR structural determination of dissolved $\mathrm{O}$-acetylated galactoglucomannan isolated from spruce thermomechanical pulp. Carbohydr. Res. 339:301-312.

Heikkinen, S., Toikka, M.M., Karhunen, P.T., Kilpeläinen, I. (2003) A. Quantitative 2D HSQC (Q-HSQC) via suppression of $J$ dependence of polarization transfer in NMR spectroscopy: application to wood lignin. J. Am. Chem. Soc. 125:43624367.

Henriksson, G., Lawoko, M., Martin, M.E.E., Gellerstedt, G. (2007) Lignin-carbohydrate network in wood and pulps: a determinant for reactivity. Holzforschung 61:668-674.

Holtman, K., Chang, H.-M., Kadla, J.F. (2004) Solution-state nuclear magnetic resonance study of the similarities between milled wood lignin and cellulolytic enzyme lignin. J. Agric. Food Chem. 52:720-726.

Hu, Z., Yeh, T.-F., Chang, H.-M., Jameel, H. (2006) Elucidation of the structure of cellulolytic enzyme lignin. Holzforschung 60:389-397.

Ibarra, D., Chávez, M.I., Rencoret, J., del Río, J.C., Gutiérrez, A., Romero, J., et al. (2007a) Lignin modification during Eucalyptus globulus kraft pulping followed by totally chlorine free bleaching: a two-dimensional nuclear magnetic resonance, Fourier transform infrared, and pyrolysis-gas chromatography/mass spectrometry study. J. Agric. Food Chem. 55: 3477-3499.

Ibarra, D., Chávez, M.I., Rencoret, J., del Río, J.C., Gutiérrez, A., Romero, J., (2007b) Structural modification of eucalypt pulp lignin in a totally chlorine free bleaching sequence including a laccase-mediator stage. Holzforschung 61:634-646.

Kilpeläinen, I., Xie, H., King, A., Granstrom, M., Heikkinen, S., Argyropoulos, D.S. (2007) Dissolution of wood in ionic liquids. J. Agric. Food Chem. 55:9142-9148. 
Kim, H., Ralph, J., Akiyama, T., Yelle, D. (2007) Gel-state NMR of ball-milled whole cell walls in DMSO- $d_{6}$ using $2 \mathrm{D}$ solutionstate NMR spectroscopy. In: Proceedings of the 10th International Congress on Biotechnology in the Pulp and Paper Industry, Madison, WI, 10-14 June 2007.

Kim, H., Ralph, J., Akiyama, T., (2008) Solution-state 2D NMR of ball-milled plant cell wall gels in DMSO- $d_{6}$. Bioenerg. Res. 1:56-66.

Lai, Y., Sarkanen, K.V. (1971) Isolation and structural studies. In: Lignins. Eds. Sarkanen, K.V., Ludwing, C. Wiley-Interscience, New York. pp. 165-240.

Liitiä, T.M., Maunu, S.L., Hortling, B., Toikka, M., Kilpeläinen, I. (2003) Analysis of technical lignins by two- and three-dimensional NMR spectroscopy. J. Agric. Food Chem. 51:21362143.

Lu, F., Ralph, J. (2002) Preliminary evidence for sinapyl acetate as a lignin monomer in kenaf. Chem. Commun. 90-91.

Lu, F.C., Ralph, J. (2003) Non-degradative dissolution and acetylation of ball-milled plant cell walls: high-resolution solutionstate NMR. Plant J. 35:535-544.

Marques, G., Gutiérrez, A., del Río, J.C., Evtuguin, D.V. (2008) Isolation and structural characterization of the acetylated heteroxylan from sisal (Agave sisalana) and its fate during alkaline pulping and TCF/ECF bleaching. In: Proceedings of the EWLP 2008, Stockholm, Sweden, 26-29 August 2008.

Martínez, A.T., Rencoret, J., Marques, G., Gutiérrez, A., Ibarra, D., Jiménez-Barbero, J., et al. (2008) Monolignol acylation and lignin structure in some nonwoody plants: a 2D NMR study. Phytochemistry 69:2831-2843.

Ralph, J. (1996) An unusual lignin from kenaf. J. Nat. Prod. 59: 341-342.

Ralph, J., Marita, J.M., Ralph, S.A., Hatfield, R.D., Lu, F., Ede, R.M., et al. (1999) Solution-state NMR of lignin. In: Advances in Lignocellulosics Characterization. Ed. Argyropoulos, D.S. Tappi Press, Atlanta, GA. pp. 55-108.

Ralph, S.A., Ralph, J., Landucci, L. (2004) NMR database of lignin and cell wall model compounds. US Forest Products Laboratory, Madison, WI. Available online at http://
ars.usda.gov/Services/docs.htm?docid=10491. (Accessed July 2006).

Rencoret, J., Marques, G., Gutiérrez, A., Ibarra, D., Li, J., Gellerstedt, G., Santos, J.I., Jiménez-Barbero, J., Martínez, A.T., del Río, J.C. (2008a) Structural characterization of milled wood lignin from different eucalypt species. Holzforschung 62:514-526.

Rencoret, J., Marques, G., Gutiérrez, A., Nieto, L., Jiménez-Barbero, J., Martínez, A.T., del Río, J.C. (2008b) “In situ” analysis of lignin by 2D-NMR of wood (Eucalyptus globulus and Picea abies) and non-woody (Agave sisalana) plant materials at the gel state. In: Proceedings of the 10th European Workshop on Lignocellulosics and Pulp. pp. 340-343. Stockholm, Sweden, 26-29 August.

Tappi Test Methods 2004-2005. Test Method no. T222 om-88. Acid-insoluble lignin in wood and pulp. Technical Association of Pulp and Paper Industries, Tappi Press, Norcoss, GA, USA, 2004

Wang, Z., Yokoyama, T., Chang, H.-M., Matsumoto, Y. (2008) Dissolution of finely milled wood into organic solvent and its potential application for chemical analysis of cell wall components. In: Proceedings of the 10th European Workshop on Lignocellulosics and Pulp (EWLP 2008), Stockholm, Sweden, 26-29 August. pp. 13-15.

Wu, S., Argyropoulos, D.S. (2003) An improved method for isolating lignin in a high yield and purity. J. Pulp Pap. Sci. 29: 235-240.

Yelle, D.J., Ralph, J., Frihart, C.R. (2008) Characterization of nonderivatized plant cell walls using high-resolution solutionstate NMR spectroscopy. Magn. Reson. Chem. 46:508-517.

Zhang, L., Gellerstedt, G. (2007) Quantitative 2D HSQC NMR determination of polymer structures by selecting the suitable internal standard references. Magn. Reson. Chem. 45:37-45.

Zhang, L., Gellerstedt, G., Ralph, J., Lu, F. (2006) NMR studies on the occurrence of spirodienone structures in lignins. J. Wood Chem. Technol. 26:65-79.

Received November 25, 2008. Accepted February 6, 2009.

Previously published online July 24, 2009. 